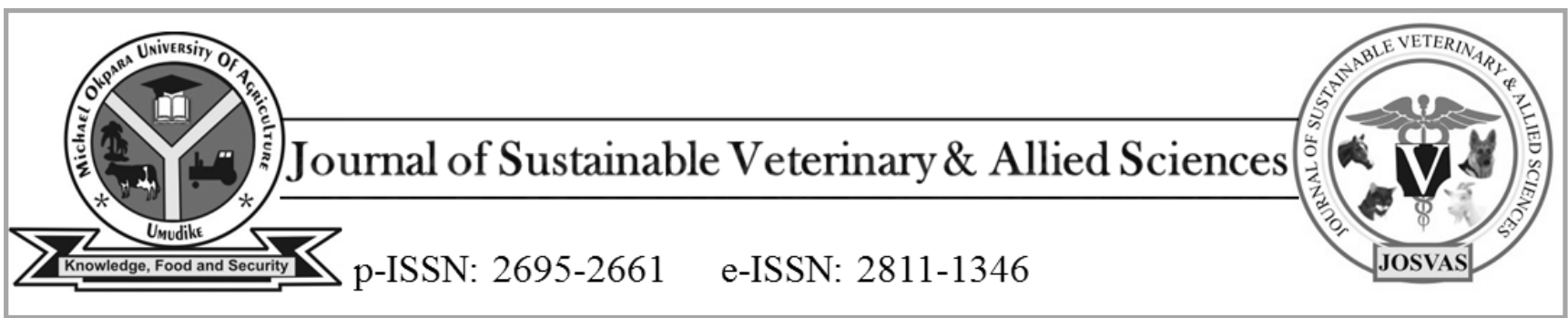

JoSVAS 2021, Vol 1, Issue 1: 78-84

C2021 College of Veterinary Medicine,

Michael Okpara University of Agriculture, Umudike, Nigeria

Original Research Article

\title{
Haematological parameters in relation to age, sex and body weight of free range village chickens (Gallus gallus domesticus) in Maiduguri, Nigeria \\ ${ }^{{ }^{*} \text { Gambo, H.I., }}{ }^{2}$ Alkali, I.M. \& ${ }^{1}$ Badau, S.J. \\ ${ }^{1}$ Department of Veterinary Pathology, ${ }^{2}$ Department of Theriogenology, Faculty of Veterinary Medicine, University of Maiduguri, Maiduguri, Borno State, Nigeria.
}

Corresponding author: halimagambo@ @unimaid.edu.ng; +234 8023646819

\begin{abstract}
The haematology of animals including chickens is an important indicator of their health status. It is therefore considered a useful tool in clinical diagnosis. The aim of this study was to investigate the haematological parameters of apparently healthy free range domesticated chickens as influenced by their sex, age and body weights. Blood samples taken from the jugular veins were analysed using standard haematological protocols. PCV, haemoglobin concentration, TRBC, TWBC, differential leukocyte counts, erythrocytes indices (MCV, MCHC and $\mathrm{MCH}$ ) were measured. The study showed that there were no significant $(\mathrm{P}>0.05)$ age-dependent variation in all the measured haematological parameters. However, sex had effect on PCV, TRBC and heterophil count. Male chickens had higher PCV value of $(34.4 \%)$ and TRBC value of $\left(2.4 \times 10^{12} / \mathrm{L}\right)$ as compared to female chickens with PCV value of $(30.5 \%)$ and TRBC value of $\left(2.1 \times 10^{12} / \mathrm{L}\right)$. On the other hand, female chickens had higher mean heterophil value of $\left(22.0 \times 10^{9} / \mathrm{L}\right)$ and MCHC value of $(29.5 \mathrm{~g} / \mathrm{dl})$ as compared to male chickens with mean heterophil and MCHC values of $\left(16.8 \times 10^{9} / \mathrm{L}\right)$ and $(25.7 \mathrm{~g} / \mathrm{dl})$ respectively. There was significant $(\mathrm{P}<0.05)$ increase in PCV with increasing body weights in males but not in females. The MCHC decreased significantly $(\mathrm{P}<0.05)$ as the body weight increased also in males but not in females. The results of the study indicate that sex and body weights influenced normal haematological parameters of apparently healthy free range domestic chickens in the study environment.
\end{abstract}

Keywords: Age, body weight, haematology, sex, village chicken.

\section{INTRODUCTION}

The local chicken (Gallus gallus domesticus) also regarded as rural or family chicken (Spradbrow, 1999) belongs to the family galliformes and is a subspecies of the red jungle fowl (Buffalo, 2003). They are natives to southern Asia, particularly the jungles of India and are believed to have originated from a continental population of Gallus gallus gallus (Fumihito et al., 1996) and spread all over the world when people domesticated them (Philips, 2010).

These chickens (Gallus gallus domesticus) are omnivores. In the wild, they often scratch the soil to search for seeds, insects and even larger animals such as lizards and young mice (Gerard, 2008). They are recognised by their morphologic features. These features are so varied that several combinations of them produce a plethora of chickens referred to as the indigenous or local chickens. Some are long-legged while others are short-legged. Majorities are full feathered while a few are frizzled-feathered. In all cases, a truly indigenous chicken is small sized and commonly weighing less than $1.2 \mathrm{~kg}$ at point of lay (Adene, 2004). Though, highly variable in plumage colour and pattern, the predominant plumage colour is perhaps the simple proof of the mongrel genetic status of the indigenous chicken (Adene, 2004).

Local chicken production is based mainly on the scavenging free-range system of management. The chickens constitute the predominant species in the rural poultry sector in Africa (Aichi, 1995). About $85 \%$ of the rural households keep chickens or other types of poultry as supplementary to the main livelihood activities in sub-Saharan Africa (Kryger et al., 2010). These local chickens remain predominant in African villages despite the introduction of exotic and crossbred strains, because farmers have not been able to afford the high input requirement of the hybrids (Kaiser, 
1990; Safalaoh, 1997). In the free range scavenging system, local chickens commonly inhabit treetops or chicken houses made of inexpensive local materials (Alders, 2001).

The local chicken flock usually comprises about 5-20 birds kept by one family and it is estimated that the village chicken makes up more than $80 \%$ of the total domestic fowl population in Africa (Gueye, 1998). Therefore, they provide household food security and a source of high value animal protein (Aichi, 1995), which invariably reduces the incidence of malnutrition in resource-poor households.

Haematological values and body weight are widely used as indices of health in large animal practice, but are not yet used widely in poultry medicine. Although, in developed countries, it is considered an integral part of clinical laboratory diagnostics in avian medicine (Sarmour, 2006). However, the use of haematological parameters in avian clinical diagnosis cannot be achieved without establishing normal reference values specific to particular species in a particular region (Brar et al., 2011). Therefore, this study aims to establish the haematological values of apparently healthy local chickens in Maiduguri as influenced by age, sex and body weight. It is hoped that the study will provide reference haematological values that would be valuable in the assessment of the health status of the local chicken in the study area.

\section{MATERIALS AND METHODS}

\section{SAMPLE POPULATION}

A total of 100 local chickens comprising young and adults were randomly procured from various households within Maiduguri Metropolis and Jere local government area. The birds were kept and provided with feeds and water ad libitum in cages for two days prior to sampling. The sexes were separated to prevent fighting and stress, which may interfere with the haematological parameters.

\section{SEXING}

The chickens were sexed using standard methods as described by Maguelonne et al. (2009). Vent sexing was performed for confirmation in young chickens when sexing based on plumage colouration was doubtful (Sargatal et al., 2013).

\section{AGING}

Age differences were estimated by plumage colouration, feather (wing and tail) development and its level of wear as described by Saether et al. (1994). Level of development of the comb, wattles and the spur may also be used to estimate age of birds (Magwisha, et al., 2002; Maina, 2005). In this study, the chickens were placed into the two age groups (young and adult) based on the above methods and information obtained from the farmers (Table I).

\section{WEIGHING}

Individual body weights of birds were taken using manual weighing scale calibrated in grams. All measurements were taken by the same person to avoid variation between individuals. Birds were divided into four groups based on the body weight as follows: W1 (600-700grams), W2 (710800grams), W3 (810-900 grams) and W4 (910-1000grams).

Table I: Features of the age groups of local free range chickens.

\begin{tabular}{l|l}
\hline $\begin{array}{l}\text { AGE } \\
\text { GROUP }\end{array}$ & FEATURES \\
\hline Young & $\begin{array}{l}\text { Presence of fuzzy natal down and juvenile } \\
\text { plumage that replaces natal down. It is dull } \\
\text { and loosely textured. }\end{array}$ \\
\hline Adult & $\begin{array}{l}\text { Presence of adult basic plumage which has } \\
\text { glossy appearance. Roosters have well } \\
\text { developed comb and wattles. Barbs of the } \\
\text { feathers have high ability to reconnect after } \\
\text { being disrupted. Rudimentary or prominent } \\
\text { spurs. }\end{array}$ \\
\hline
\end{tabular}

Source: (Sargatal, et al., 2013).

\section{SAMPLE COLLECTION}

Five millilitres of blood was aseptically collected using $5 \mathrm{ml}$ sterile syringe from the right jugular vein (Samour, 2006). The needle was removed and the blood carefully dispensed into sample bottles containing EDTA as anticoagulant. All samples were collected early in the morning and taken to the laboratory within 30 minutes of sampling for analysis.

\section{HAEMATOLOGY}

Packed cell volume (PCV) was determined using the standard micro haematocrit method as described by Brar et. al. (2011). Haemoglobin concentration was determined using the cyanmethaemoglobin method as described by Brar et al. (2011). Total red blood cell (TRBC) and total white counts blood cell (TWBC) were carried out using the standard Natt and Herrick's method as described by Campbell (1995). The differential leukocyte count was carried out as described by Sarmour (2006).

\section{STATISTICAL ANALYSIS}

The results were summarized as Means \pm Standard deviations. Means were compared using student's t-test for differences in age and sex while a one-way analysis of variance with Turkey post-hoc test was used to compare difference in body weights using computer software [GraphPad Instat, 1993]. 


\section{RESULTS}

THE EFFECT OF SEX ON HAEMATOLOGICAL PARAMETERS OF APPARENTLY HEALTHY LOCAL CHICKENS IN MAIDUGURI.

The mean values of haematological parameters of male and female chickens are presented in Table II. Significant ( $p$ $<0.05)$ variations were observed in the mean PCV (34.4\% in males and $30.5 \%$ in females), total erythrocyte count (TRBC) $\left(2.4 \times 10^{12} / \mathrm{L}\right.$ in males and $2.1 \times 10^{12} / \mathrm{L}$ in females $)$, MCHC $(25.7 \mathrm{~g} / \mathrm{dl}$ in males and $29.5 \mathrm{~g} / \mathrm{dl}$ in females) and heterophil counts $\left(16.8 \times 10^{9} / \mathrm{L}\right.$ in males and $22.0 \times 10^{9} / \mathrm{L}$ in females) between male and female village chickens. The mean PCV and total erythrocyte count were significantly $(\mathrm{P}<0.05)$ higher in males; while $\mathrm{MCHC}$ and heterophil counts were significantly $(\mathrm{P}<0.05)$ higher in females. There were no variations in the other haematological parameters between males and female chickens

\section{THE EFFECT OF AGE ON HAEMATOLOGICAL PARAMETERS OF APPARENTLY HEALTHY LOCAL CHICKENS IN MAIDUGURI}

The haemogram of the apparently healthy village chickens based on different age groups is presented in Table III. Age had no significant $(\mathrm{P}>0.05)$ effect on haematological parameters of local chickens in the study area. .

\section{THE EFFECT OF BODY WEIGHT ON HAEMATOLOGICAL PARAMETERS OF APPARENTLY HEALTHY LOCAL CHICKENS IN MAIDUGURI}

The mean values of the haematological parameters of apparently healthy village chickens based on body weights are presented in Table IV. The PCV was significantly higher $(\mathrm{P}<0.05)$ in groups W3 $(34.2 \%)$ and $\mathrm{W} 4(34.6 \%)$ as compared to $\mathrm{W} 1(30.4 \%)$ and $\mathrm{W} 2(31.1 \%)$. MCHC values were significantly $(\mathrm{P}<0.05)$ higher in $\mathrm{W} 1(29.5 \mathrm{~g} / \mathrm{dl})$, W2 $(29.9 \mathrm{~g} / \mathrm{dl})$ and W3 (25.6g/dl) as compared to W4 (23.7g/dl). Body weight had no significant $(\mathrm{P}<0.05)$ effect on the remaining haematological parameters.

Full blood count of 100 apparently healthy scavenger chickens presented in Table $\mathrm{V}$ showed the mean values of all the haematological parameters and reference ranges for each parameter.

Table II: Haemogram (Mean \pm SD) of apparently healthy male and female village chickens (Gallus gallus domesticus) in Maiduguri

\begin{tabular}{l|l|l}
\hline $\begin{array}{l}\text { Haematological } \\
\text { parameters }\end{array}$ & Male $(\mathrm{n}=39)$ & Female $(\mathrm{n}=61)$ \\
\hline $\mathrm{PCV}(\%)$ & $34.4 \pm 3.5^{\mathrm{a}}$ & $30.5 \pm 4.2^{\mathrm{b}}$ \\
$\mathrm{Hb}(\mathrm{g} / \mathrm{dl})$ & $8.8 \pm 2.2^{\mathrm{a}}$ & $8.9 \pm 2.3^{\mathrm{a}}$ \\
$\mathrm{TRBC} \times 10^{12} / \mathrm{L}$ & $2.4 \pm 0.5^{\mathrm{a}}$ & $2.1 \pm 0.3^{\mathrm{b}}$ \\
$\mathrm{TWBC} \times 10^{9} / \mathrm{L}$ & $45.6 \pm 18.7^{\mathrm{a}}$ & $41.2 \pm 17.4^{\mathrm{a}}$ \\
MCHC $(\mathrm{g} / \mathrm{dl})$ & $25.7 \pm 6.4^{\mathrm{a}}$ & $29.5 \pm 7.1^{\mathrm{b}}$ \\
MCV $(\mathrm{fl})$ & $149.3 \pm 28.9^{\mathrm{a}}$ & $146.8 \pm 29.6^{\mathrm{a}}$ \\
MCH $(\mathrm{pg})$ & $38.8 \pm 14.4^{\mathrm{a}}$ & $43.2 \pm 13.5^{\mathrm{a}}$ \\
Heterophils $\left(\times 10^{9} / \mathrm{L}\right)$ & $16.8 \pm 9.1^{\mathrm{a}}$ & $22.0 \pm 13.6^{\mathrm{b}}$ \\
Lymphocytes & $13.1 \pm 7.4^{\mathrm{a}}$ & $14.2 \pm 5.6^{\mathrm{a}}$ \\
$\left(\times 10^{9} / \mathrm{L}\right)$ & & \\
Monocytes $\left(10^{9} / \mathrm{L}\right)$ & $3.4 \pm 2.7^{\mathrm{a}}$ & $2.5 \pm 2.2^{\mathrm{a}}$ \\
Eosinophil $\left(\times 10^{9} / \mathrm{L}\right)$ & $2.4 \pm 2.3^{\mathrm{a}}$ & $1.9 \pm 1.9^{\mathrm{a}}$ \\
Basophil $\left(\times 10^{9} / \mathrm{L}\right)$ & $0.2 \pm 0.6^{\mathrm{a}}$ & $0.1 \pm 0.4^{\mathrm{a}}$ \\
Thrombocytes & $5.3 \pm 4.1^{\mathrm{a}}$ & $5.0 \pm 3.7^{\mathrm{a}}$ \\
$\left(\times 10^{9} / \mathrm{L}\right)$ & & \\
\hline
\end{tabular}

\footnotetext{
${ }^{\mathrm{ab}}$ Mean \pm SD along rows with different superscripts are significant at $\mathrm{P}<0.05$
}

Table III: Haemogram (Mean \pm SD) of Different Age Groups of Apparently Healthy Village Chickens (Gallus Gallus domesticus) In Maiduguri

\begin{tabular}{l|l|l}
\hline $\begin{array}{l}\text { Haematological } \\
\text { parameters }\end{array}$ & Young $(\mathbf{n}=\mathbf{7 7})$ & Adult $(\mathbf{n}=23)$ \\
\hline PCV $(\%)$ & $32.5 \pm 2.9^{\mathrm{a}}$ & $30.4 \pm 6.1^{\mathrm{a}}$ \\
$\mathrm{Hb}(\mathrm{g} / \mathrm{dl})$ & $9.0 \pm 2.6^{\mathrm{a}}$ & $8.0 \pm 1.8^{\mathrm{a}}$ \\
$\mathrm{TRBC} \times 10^{12} / \mathrm{L}$ & $2.3 \pm 0.4^{\mathrm{a}}$ & $2.2 \pm 0.4^{\mathrm{a}}$ \\
$\mathrm{TWBC} \times 10^{9} / \mathrm{L}$ & $44.6 \pm 17.0^{\mathrm{a}}$ & $41.8 \pm 15.0^{\mathrm{a}}$ \\
$\mathrm{MCHC}(\mathrm{g} / \mathrm{dl})$ & $27.5 \pm 6.9^{\mathrm{a}}$ & $27.1 \pm 7.2^{\mathrm{a}}$ \\
$\mathrm{MCV}(\mathrm{fl})$ & $142.5 \pm 28.5^{\mathrm{a}}$ & $141.2 \pm 32.2^{\mathrm{a}}$ \\
MCH $(\mathrm{pg})$ & $39.5 \pm 12.0^{\mathrm{a}}$ & $38.1 \pm 13.9^{\mathrm{a}}$ \\
Heterophils $\left(\times 10^{9} / \mathrm{L}\right)$ & $20.8 \pm 9.7^{\mathrm{a}}$ & $17.4 \pm 7.1^{\mathrm{a}}$ \\
Lymphocytes & $13.3 \pm 6.3^{\mathrm{a}}$ & $14.3 \pm 8.6^{\mathrm{a}}$ \\
$\left(\times 10^{9} / \mathrm{L}\right)$ & & $3.0 \pm 2.6^{\mathrm{a}}$ \\
Monocytes $\left(\times 10^{9} / \mathrm{L}\right)$ & $3.4 \pm 2.1^{\mathrm{a}}$ & $2.2 \pm 1.8^{\mathrm{a}}$ \\
Eosinophil $\left(\times 10^{9} / \mathrm{L}\right)$ & $2.0 \pm 1.9^{\mathrm{a}}$ \\
$\begin{array}{l}\text { Basophil }\left(\times 10^{9} / \mathrm{L}\right) \\
\text { Thrombocytes }\end{array}$ & $0.2 \pm 0.4^{\mathrm{a}}$ & $0.3 \pm 0.7^{\mathrm{a}}$ \\
$\left.\times 10^{9} / \mathrm{L}\right)$ & $5.0 \pm 2.8^{\mathrm{a}}$ & $4.6 \pm 3.4^{\mathrm{a}}$ \\
\hline ab Mean $\pm \mathrm{SD}$ along rows with different superscripts are \\
significant at P<0.05
\end{tabular}




\section{DISCUSSION}

Haematological parameters in birds have been shown to be influenced by several factors among which are sex, age, nutrition season of the year, breeds (strains), body weight (Sturkie, 1965; Oyewale, 1990) and diurnal fluctuation and changes in physical and metabolic activities (Sanni et al., 2000; Piccione et al., 2001, 2005). In this study, the PCV and the total erythrocyte count were significantly higher in male chickens which were comparable to findings from indigenous chickens in Sudan (Elagib \& Ahamed, 2011), golden local quails (Muhammad, 2013) and free range guinea fowl (King et al., 2010). Generally, PCV percentage in males is greater than female fowls (Bowes et al., 1989; Simaraks et al., 2004; Pampori \& Igbal, 2007; Addass et al., 2012; Abdi-Hachesoo et al., 2013). This may be due to the increased erythropoiesis and metabolic activities influenced by androgens in males (Coles, 1986; Sembulingam, 2010) as androgens and thyroxin are reported to stimulate erythropoiesis, whereas estrogen depresses erythropoiesis (Herbert et al., 1989) which accounts for the lower PCV in females. In contrast, Nowaczewski and Kontecka (2012) reported lower values in male broiler chickens. Among the erythrocyte indices, only MCHC showed significantly higher values in females than in males as opposed to findings reported by Elagib and Ahamed (2011).

In general, this study showed higher total leukocyte values $\left(42.9 \pm 17.9 \times 10^{9} / \mathrm{L}\right)$ than those reported in intensively managed broiler chickens $\left(32.6 \pm 1.7 \times 10^{9} / \mathrm{L}\right)$

Table IV: Haemogram (Mean \pm SD) of apparently healthy village chickens (Gallus gallus domesticus) in Maiduguri based on their individual weights.

\begin{tabular}{|c|c|c|c|c|}
\hline \multirow[t]{2}{*}{ Haematological Parameters } & \multicolumn{4}{|l|}{ Weight in Grams } \\
\hline & $\mathrm{W} 1(600-700) \mathrm{n}=25$ & W2 (710-800) $n=40$ & W3 (810-900)n=22 & W4 (910-1000)n=13 \\
\hline $\mathrm{PCV}(\%)$ & $30.4 \pm 3.9^{\mathrm{a}}$ & $31.1 \pm 4.9^{\mathrm{a}}$ & $34.2 \pm 3.1^{b}$ & $34.6 \pm 3.4^{b}$ \\
\hline $\mathrm{Hb}(\mathrm{g} / \mathrm{dl})$ & $8.9 \pm 1.9^{\mathrm{a}}$ & $9.2 \pm 2.4^{\mathrm{a}}$ & $8.8 \pm 2.1^{\mathrm{a}}$ & $8.0 \pm 2.3^{\mathrm{a}}$ \\
\hline $\mathrm{TRBC} \times 10^{12} / \mathrm{L}$ & $2.2 \pm 0.4^{\mathrm{a}}$ & $2.2 \pm 0.5^{\mathrm{a}}$ & $2.4 \pm 0.4^{\mathrm{a}}$ & $2.3 \pm 0.3^{\mathrm{a}}$ \\
\hline $\mathrm{TWBC} \times 10^{9} / \mathrm{L}$ & $39.6 \pm 15.9^{\mathrm{a}}$ & $42.9 \pm 19.2^{\mathrm{a}}$ & $45.5 \pm 16.5^{\mathrm{a}}$ & $45.6 \pm 20.9^{\mathrm{a}}$ \\
\hline $\mathrm{MCHC}(\mathrm{g} / \mathrm{dl})$ & $29.5 \pm 6.4^{\mathrm{a}}$ & $29.9 \pm 7.3^{\mathrm{a}}$ & $25.6 \pm 5.8^{\mathrm{a}}$ & $23.7 \pm 6.7^{\mathrm{b}}$ \\
\hline $\operatorname{MCV}(\mathrm{fl})$ & $144.1 \pm 29.3^{\mathrm{a}}$ & $148.9 \pm 34.7^{\mathrm{a}}$ & $147.8 \pm 21.4^{\mathrm{a}}$ & $151.2 \pm 23.7^{\mathrm{a}}$ \\
\hline $\mathrm{MCH}(\mathrm{pg})$ & $42.5 \pm 12.7^{\mathrm{a}}$ & $44.4 \pm 15.4^{\mathrm{a}}$ & $37.8 \pm 10.3^{a}$ & $36.8 \pm 15.7^{\mathrm{a}}$ \\
\hline Heterophils $\left(\times 10^{9} / \mathrm{L}\right)$ & $17.8 \pm 11.4^{\mathrm{a}}$ & $17.5 \pm 10.2^{\mathrm{a}}$ & $21.2 \pm 13.1^{\mathrm{a}}$ & $21.1 \pm 11.4^{\mathrm{a}}$ \\
\hline Lymphocytes $\left(\times 10^{9} / \mathrm{L}\right)$ & $13.7 \pm 7.3^{\mathrm{a}}$ & $13.5 \pm 7.5^{\mathrm{a}}$ & $13.8 \pm 4.9^{\mathrm{a}}$ & $13.0 \pm 6.8^{\mathrm{a}}$ \\
\hline Monocytes $\left(\times 10^{9} / \mathrm{L}\right)$ & $2.6 \pm 1.8^{\mathrm{a}}$ & $3.5 \pm 3.0^{\mathrm{a}}$ & $2.4 \pm 1.8^{\mathrm{a}}$ & $3.7 \pm 3.1^{\mathrm{a}}$ \\
\hline Eosinophil $\left(\times 10^{9} / \mathrm{L}\right)$ & $2.0 \pm 2.1^{\mathrm{a}}$ & $2.5 \pm 2.4^{\mathrm{a}}$ & $1.7 \pm 1.2^{\mathrm{a}}$ & $2.7 \pm 2.8^{\mathrm{a}}$ \\
\hline Basophil $\left(\times 10^{9} / \mathrm{L}\right)$ & $0.2 \pm 0.6^{\mathrm{a}}$ & $0.3 \pm 0.6^{\mathrm{a}}$ & $0.2 \pm 0.3^{\mathrm{a}}$ & $0.1 \pm 0.1^{\mathrm{a}}$ \\
\hline Thrombocytes $\left(\times 10^{9} / \mathrm{L}\right)$ & $3.2 \pm 2.4^{\mathrm{a}}$ & $5.8 \pm 4.5^{\mathrm{b}}$ & $6.3 \pm 4.0^{\mathrm{c}}$ & $5.2 \pm 3.2^{\mathrm{a}}$ \\
\hline
\end{tabular}

${ }^{\mathrm{ab}}$ Mean \pm SD along rows with different superscripts are significant at $\mathrm{P}<0.05$

Table V: Full blood count of apparently healthy local scavenger chickens (Gallus gallus domesticus) in Maiduguri

\begin{tabular}{|c|c|c|c|c|c|}
\hline Parameters & $\begin{array}{ll}\text { No. } & \text { of } \\
\text { chickens }\end{array}$ & Minimum value & Maximum value & Mean \pm SD & Range \\
\hline $\operatorname{PCV}(\%)$ & 100 & 19.00 & 44.00 & $32.0 \pm 4.4$ & $19-44$ \\
\hline $\mathrm{Hb}(\mathrm{g} / \mathrm{dl})$ & 100 & 4.50 & 15.80 & $8.9 \pm 2.2$ & $5-15$ \\
\hline $\mathrm{TRBC} \times 10^{12} / \mathrm{L}$ & 100 & 1.41 & 4.04 & $2.2 \pm 0.4$ & $1.4-4$ \\
\hline $\mathrm{TWBC} \times 10^{9} / \mathrm{L}$ & 100 & 14.50 & 98.50 & $42.9 \pm 17.9$ & $15-98$ \\
\hline MCHC (g/dl) & 100 & 14.52 & 49.38 & $28.0 \pm 7.0$ & $15-49$ \\
\hline MCV (fl) & 100 & 91.74 & 228.76 & $147.8 \pm 29.2$ & $91-229$ \\
\hline $\mathrm{MCH}(\mathrm{pg})$ & 100 & 21.37 & 80.39 & $41.5 \pm 13.9$ & $21-80$ \\
\hline Heterophils $\times 10^{9} / \mathrm{L}$ & 100 & 5.25 & 66.98 & $18.8 \pm 11.3$ & $5-66$ \\
\hline Lymphocytes $\times 10^{9} / \mathrm{L}$ & 100 & 3.19 & 37.99 & $13.5 \pm 6.7$ & $3-38$ \\
\hline Eosinophils $\times 10^{9} / \mathrm{L}$ & 100 & 0.00 & 11.28 & $2.2 \pm 2.2$ & $0-11$ \\
\hline Monocytes $\times 10^{9} / \mathrm{L}$ & 100 & 0.00 & 12.35 & $3.0 \pm 2.5$ & $0-12$ \\
\hline Basophils $\times 10^{9} / \mathrm{L}$ & 100 & 0.00 & 2.58 & $0.2 \pm 0.5$ & $0-3$ \\
\hline Thrombocytes $\times 10^{9} / \mathrm{L}$ & 100 & 0.00 & 18.33 & $5.2 \pm 3.9$ & $0-18$ \\
\hline
\end{tabular}


(Nowaczewski, 2012). This may explain why extensively managed scavenger chickens are relatively resistant to some diseases (Talabi et al., 2005). In a study by Bayona et al. (2017) in chickens, leucocytes (predominantly heterophils) were seen to be rapidly mobilized to site of acute inflammation as early as 4 hours and reached a peak at 12 hours post challenge; with heterophils and monocyte/macrophages being the main contributors of reactive oxygen species (ROS) production. However, only heterophil count showed significant $(\mathrm{P}<0.05)$ variation with higher values in females which may reflect the physiological stress due to laying in adult females (Talabi et al., 2005; Muhammad, 2013). Some workers (Maxwell \& Robertson, 1998; Puvadolpirod \& Thaxton, 2000; Davis et al., 2008) have reported the use of the heterophil/lymphocyte ratio as an indicator of physiological stress in the avian specie. This is because heterophils increase during mild or moderately stressful conditions. The higher heterophil values in females in this study are similar to reports by Muhammed (2013) in golden quails and Talabi et al. (2005) in broiler hybrids. In contrast, results of lower values were reported by AbdiHachesoo et al. (2013). Heterophils were observed to be the most abundant leukocyte in this study. This may be because of the scavenging nature of the birds which makes them prone to stressful conditions and heterophils have been reported to increase in mild or moderately stressful conditions (Puvadolpirod \& Thaxton, 2000; Davis et al., 2008). Similar findings were made by Aroch et al. (2013) whereas in some avian species, lymphocytes were reported to be the predominant cell type (Latimer et al., 1988; Fudge, 2000; Schmidt et al., 2009).

Age had no significant influence on all the haematological parameters in this study. This is in contrast to findings in broiler hybrids by Talabi et al. (2005) who reported that, with increasing age, the erythrocytic parameters (except $\mathrm{MCV}, \mathrm{MCH}$ and MCHC) and leukocytic parameters (except heterophils and heterophil/lymphocyte ratio) were significantly increased. Similar observation was made by Muhammad (2013) where the haematological parameters increased in direct proportion to age in golden quails. This also agrees with an age related haematological findings in Kori Bustard (Aedeotiskori) chicks (Sarmour, 2006) where there was steady increase in their haematological parameters between 1-4 months of age although, this was followed by about 5 months of plateau, where no rise in haematological values were observed. Increase in haematological parameters of avian specie has mostly been reported in adult birds probably because of the effect of sexual hormones such as androgens on blood parameters. This may explain why no significant variations were observed between the various age groups because most of the birds sampled in this study were within the age range of 4-10 months.
Packed cell volume (PCV) values in this study showed a significant increase with increasing body weight. This may be attributed to the increasing energy demand by the body, increasing growth rate and high production of metabolic hormones with resultant release of large numbers of erythrocytes into circulation (Fair et al., 2007; Aina \& Ajibade, 2014; Sujata et al., 2014). In contrast, the MCHC decreased significantly with increasing body weight and this may be explained by the increases in PCV values.

\section{CONCLUSION}

Haematological parameters of village chickens in the study area were influenced by sex and to a lesser extent by their individual body weights, with no influence due to different age of the chickens.

\section{ACKNOWLEDGEMENT}

The authors will like to thank Malam Samaila Gadaka for his technical assistance in running the haematology tests.

\section{CONFLICT OF INTEREST}

The authors have no conflict of interest to declare.

\section{REFERENCES}

Abdi-Hachesoo, B., Talabi, A., Asri-Razaei, S. \& Basaki, M. (2013). Sex related differences in biochemical and haematological parameters of adult indigenous chickens in Northwest of Iran. Journal of Animal Science Advances, 3(10), 512-516.

Addass, P.A., David, D.L., Edward, A., Zira, K.E. \& Midau, A. (2012). Effect of age, sex and management system on some haematological parameters of intensively and semi-intensively kept chickens in Mubi, Adamawa State, Nigeria. Iranian Journal of Applied Animal Science, 2(3), 277-282.

Adene, D.E. (2004). Poultry health and productionprinciples and practices (1st ed.). Ibadan, Nigeria: Stirling-Horden Publishers.

Aichi, J.K. (1995). Village chicken production system in rural Africa household food security and gender issues. Publication of the food and agricultural organisation of United Nation (FAO, 1998), Paper 142. ISBN: 92-5-164160-1

Aina, O.O. \& Ajibade T (2014). Age- related changes in haematologic parameters of cage-raised Japanese quails (Cortunix japonica). Journal of Veterinary Medicine and Animal Health, 6 (4), 104-108.

Alders, R. \& Spradbrow, P. (2001). Controlling Newcastle disease in village chicken ACIAR Monograph No.82 pp 112.

Aroch, I., Targan, N. \& Gancz, A.Y. (2013). A novel modified semi-direct method for total leukocyte count in birds. Israel Journal of Veterinary Medicine, 68 (2), 111-118.

Bayona, J.A.M., Karuppannam, A.K \& Barreda, D.R. (2017). Contribution of leucocytes to the induction and resolution of the acute inflammatory response in chickens. Developmental comparative Immunology, 74, 167-177. 
Bowes, V.A., Julian, R.J. \& Stirtzinger, T. (1989). Comparison of serum biochemical profiles of male broilers with female broilers and white leghorn chickens. Canadian Journal of Veterinary Research, 53, 7-11.

Brar, R.S., Sandhu, H.S. \& Singh, A. (2011). Veterinary clinical diagnosis by laboratory methods (1st ed.). India: Kalyani Publishers.

Campbell, T.W. (1995). Avian hematology and cytology. Ames: Iowa State University Press.

Coles, E.H. (1986). Veterinary clinical pathology (4th ed.). Philadelphia: Saunders.

Cowell, R. (2004). Veterinary clinical pathology secrets (1st ed.). Elsevier Mosby Publishers.

Davis, A.K., Maney, D.L. \& Maerz, J.C (2008). The use of leucocyte profiles to measure stress in vertebrates: a review for ecologists. Functional Ecology, 22, 760772.

Elagib, H.A.A. \& Ahmed, A.D.A. (2011). Comparative study on haematological values of blood of indigenous chickens in Sudan. Asian Journal of Poultry Science, 5(1), 41-45.

Fair, J., Whitaker, S. \& Pearson, B. (2007). Sources of variation in haematocrit in birds. Ibis, 149, 535552.

Fudge, A.M. (2000). Laboratory Medicine: Avian and Exotic Pets. (1st ed,). Philadelphia: W.B. Saunders.

Fumihito, A., Miyake, T., Sumi, S., Takada, M., Ohno, S., \& Kondo, N. (1994), "One subspecies of the red junglefowl (Gallus gallus gallus) suffices as the matriarchic ancestor of all domestic breeds". Proceedings of the National Academy of Science, 91 (26), 12505-12509.

Graphpad instat (2000), version 3.05, 32 bit.Graphpad software, Inc.

Gerard, P.W. (2008). AKA "Farmer Jerry"."Frequently asked questions about chickens and eggs"(http://gworrell.freeyellow.com/chickenfaq.ht $\mathrm{ml})$. Ferry Landing Farm \& Apiary.

Gueye, E.F. (1998). Village egg and fowl meat production in Africa. World Poultry Science Journal, 54, 7386.

Herbert, R., Nanney., Spano, J.S., Pedersoli, W.M. \& Krista, L.M. (1989). Erythrocyte distribution in ducks. American Journal of Veterinary Research, 50, 958960.

Ikani, E.I. \& Innatte, A.I. (2000). Improving the performance of local chickens. Extension Bulletin No.92, Poultry series No. 6, National agricultural extension and research liason services ABU Zaria.

Kaiser, D. (1990) Improvement of traditional poultry keeping in Niger. In Proceedings: CTA Seminar, 3rd International Symposium on Poultry Production in Hot Climates, Hameln Germany.

King, S., Ntombi, B. \& Maxwell, M. (2010). Indices of health : clinical haematology and body weight of free-range Guinea fowl (Numida maleagris) from sourthen province of Zambia, International Journal of Poultry Science, 9(12),1083-1086.

Latimer, K.S., Tang, K.N., Goodwin, M.A., Steffens, W.L. \& Brown, J. (1988). Leukocyte changes associated with acute inflammation in chickens. Avian Disease, 32, 760-772.

Maguelonne, T.S. (2009). The History of Poultry In Anthea Bell's The History of Food, (Revised ed., p. 306). John Wiley and Sons.

Magwisha, H.B., Kassuku, A.A., Kvysgaard, N.C. \& Permin, A. (2002). A comparison of the prevalence and burdens of helminth infections in growers and adult free- range chickens. Tropical Animal Health and Production, 34(1), 205-214.

Maina, A.N. (2005). Prevalence, intensity and lesions associated with gastrointestinal parasites of indigenous chicken in Kenya MSc. Thesis, University of Nairobi.

Maxwell, M.H \& Robertson, G.W (1998). The avian heterophil: a review. World's Poultry Science Journal 54(2), 155-178.

Muhammad, H.K. (2013). Study of the effect of age and sex on some haematological parameters in golden local quail. Bas. Journal of Veterinary Research, 12(1), 135-141.

Nowaezewski, S. \& Kontecka, H. (2012), Haematological indices size of erythrocytes and haemoglobin saturation in Broiler Chickens kept in commercial conditions, Animal Science Papers and Reports, 30(2), 181-190.

Oyewale, J.O. \& Alajibade H.A. (1990). Osmotic fragility of erythrocytes in two age-groups of turkey. Veterinaski Arhiv, 60,43-48.

Pampori, Z.A. \& Igbal, S. (2007). Haematology, serum chemistry and electrocardiographic evaluation in native chicken of Kashmir. International Journal of Poultry Science, 6, 578-582.

Phillip, J.C. (2010) "Incubating Eggs".Virginia Cooperative Extension Service, Virginia State University.

Piccione, G., Assenza, A., Fazio, F., Giudice, E. \& Caola, G. (2001). Different periodicity of some haematological parameters in exercise-loaded and sedentary horses. Journal of Equine Science, 12, 17-23.

Piccione, G., Fazio, F., Giudice, E., Grasso, F. \& Morgante, M. (2005). Nycthemeral change of some haematological parameters in horses. Journal of Applied Biomedicine, 3, 123-128.

Puvadolpirod, S. \& Thaxton, J.P (2000). Model of physiological stress in chickens 1response parameters. Poultry Science 79(3), 363-369.

Saether, S.A., Kalas, J.A. \& Fiske, P. (1994). Age determination of breeding shorebirds: quantification of feather wear in the lekking great snipe. Condor, 96,959-972.

Safalaoh, A.C.L. (1997). Characteristics of indigenous chickens of Malawi. Animal Genetic Resources Information, 22, 61-69.

Sanni, A.A., Oyedokun, O.R. \& Alaka, O.O. (2000). Preliminary observations on diurnal rhythm in the haematological parameters of male African giant rats (Cricotomys gambianus) African Journal of Biomedical Research, 3, 117-120.

Sargatal, J. \& David, A.C. (Eds.) (2013). Birds of the world. Lynx Edicons: Spanish publishing house. 
Sarmour, J. (2006). Clinical avian medicine (3rd ed.). London: Mosby International.

Schmidt, E.M., Paulillo, A.C., Martins, G.R.V., Lapera, I.M., Testi, A.G.P., Junior, L.N., Denadai, J. \& Fagliari, J.J. (2009). Hematology of the bronze turkey (Meleagris gallopavo): Variations with Age and Gender. International Journal of Poultry Science, 8(8), 752-754.

Sembulingam, K,. \& Sembulingam, P. (2010). Essentials of Medical Physiology $\left(5^{\text {th }}\right.$ ed). India: Jaypee Publishers.

Simaraks, S., Chinrasri, O. \& Aengwanich, W. (2004). Hematological, electrolyte and serum biochemical value of the Thai indigenous chickens (Gallus domesticus) in northeastern Thailand. Songklanakarin Journal of Scence and Technology, 26, 425-430.

Sonaiya, E.B. (1990a). The context and prospects for development of smallholder rural poultry production in Africa. In Proceedings, CTA Seminar on Smallholder Rural Poultry Production, Thessaloniki, Greece, 9-13 October 1990, Vol. 1, p. 35-52.
Spradbrow, P.B. (1999) Epidemiology of Newcastle disease and the economics of its control, In: Poultry as a tool in poverty eradication and promotion of gender equality Proceedings of a work shop.

Sturkie, P.D. (1965). Avian physiology (2nd ed.) New York: Comstock Publishing Associates, Cornel University Press.

Sujata, P., Mohanty, P.K. \& Mallik, B.K. (2014). Haematological analyses of Japanese Quail (Coturnix Coturnix Japonica) at different stages of growth. International Research Journal of Biological Sciences, 3 (11), 51-53.

Talabi, A., Asri-Rezaei, S., Rozeh-chai, R., and Sahraei, R. (2005). Comparative studies on haematological values of broiler strains. Internation Journal of Poultry Science, 4(8), 573-579

Article history:

Received: July 1, 2021,

Revised: August 28, 2021,

Accepted: August 29, 2021 